\title{
Angiotensinogen Gene Is Expressed and Differentially Regulated in Multiple Tissues of the Rat
}

\author{
Duncan J. Campbell and Joel F. Habener \\ Laboratory of Molecular Endocrinology and Howard Hughes Medical Institute, Massachusetts General Hospital and Harvard Medical \\ School, Boston, Massachusetts 02114
}

\begin{abstract}
To define the role of local synthesis of angiotensinogen in tissue angiotensin production, we have quantitated angiotensinogen messenger RNA (mRNA) levels in 17 different tissues of four groups of rats: control rats, nephrectomized rats, rats given dexamethasone, ethynylestradiol, and triiodothyronine, and nephrectomized rats given dexamethasone, ethynylestradiol, and triiodothyronine. Angiotensinogen mRNA was identified in 12 tissues: liver, kidney, brain, spinal cord, aorta, mesentery, atria, lung, adrenal, large intestine, stomach, and spleen. Angiotensinogen mRNA was not identified in pituitary, ventricle, testis, small intestine, or pancreas. When expressed per gram tissue wet weight, angiotensinogen mRNA levels of extrahepatic tissues were $<4 \%$ of hepatic levels. However, when expressed per milligram total RNA, angiotensinogen mRNA levels of brain, spinal cord, aorta, and mesentery were $26-42 \%$ of hepatic levels. Regulation of angiotensinogen mRNA levels was tissue specific. This demonstration of a widespread tissue distribution of angiotensinogen mRNA may indicate a similarly widespread distribution of local angiotensin systems that are independent of the circulating renin-angiotensin system.
\end{abstract}

\section{Introduction}

Angiotensin II is a major determinant of blood pressure, fluid, and electrolyte homeostasis. In addition to its potent vasoconstrictor effects, vascular actions of angiotensin II include the stimulation of prostaglandin release, the modulation of angiotensin II receptor number, and the stimulation of angiogenesis (1-3). Angiotensin II also has important actions in the central and peripheral nervous systems, the adrenal, kidney, intestine, and heart (4-9).

Accumulating evidence indicates that peripheral tissues are a major site of production of angiotensin (10). However, the role of plasma renin and angiotensinogen, as opposed to that of locally synthesized components, in local angiotensin production is not known. Whereas many different enzymes are able to cleave angiotensinogen (renin substrate) to release angiotensin I or an-

This work was presented in part at the 67th Annual Meeting of the Endocrine Society, Baltimore, MD, 1985, as abstract 450.

Address correspondence and reprint requests to Dr. Campbell, Laboratory of Molecular Endocrinology, Massachusetts General Hospital, Boston, MA 02114.

Received for publication 19 September 1985 and in revised form 10 January 1986.

J. Clin. Invest.

(c) The American Society for Clinical Investigation, Inc.

0021-9738/86/07/0031/09 \$1.00

Volume 78, July 1986, 31-39 giotensin II (11-22), angiotensinogen is the only known precursor of the angiotensin peptides. Thus, synthesis of angiotensinogen is an obligatory requirement for an independent tissue angiotensin system. Both liver and brain are established sites of angiotensinogen synthesis (23-26). We have sought evidence for synthesis of angiotensinogen in other tissues using the technique of Northern blot analysis of tissue RNA to identify and quantitate angiotensinogen messenger RNA (mRNA) in each tissue. Identification of angiotensinogen mRNA was confirmed by nuclease S1 protection assay.

Both bilateral nephrectomy and the administration of dexamethasone (Dex), ${ }^{1}$ ethynylestradiol $\left(\mathrm{E}_{2}\right)$, and triiodothyronine $\left(\mathrm{T}_{3}\right)$ stimulate liver angiotensinogen production and increase translatable levels of liver angiotensinogen mRNA (23-27). We have used these stimuli in the present study so as to increase the probability of detection of angiotensinogen mRNA in tissues with low angiotensinogen mRNA levels, and also to compare the regulation of angiotensinogen $m R N A$ in different tissues.

\section{Methods}

Tissues were obtained from four groups of male Sprague-Dawley rats ( $\sim 400 \mathrm{~g}$ ): control rats, rats nephrectomized $24 \mathrm{~h}$ before killing $(\mathrm{Nx})$, rats given, by subcutaneous injection, dexamethasone $(7 \mathrm{mg} / \mathrm{kg}), 17 \alpha$-ethynylestradiol $(3 \mathrm{mg} / \mathrm{kg})$ and 3,3',5-triiodothyronine $(40 \mu \mathrm{g} / \mathrm{kg}) 24 \mathrm{~h}$ before killing (Dex, $E_{2}, T_{3}$ ), and nephrectomized $(\mathrm{Nx})$ rats given Dex, $E_{2}$, and $\mathrm{T}_{3} 24 \mathrm{~h}$ before killing.

17 different tissues were studied: liver, spleen, kidney, pancreas (the whole pancreas including enveloping adipose tissue), stomach (extending from gastroesophageal junction to pylorus), small intestine (including duodenum and proximal jejunum), large intestine (extending from cecum to transverse colon), adrenals (stripped of adherent fat and connective tissue), testes (not including epididymis), lung, atria (both atria with small cuff of ventricular muscle), ventricles (both ventricles), aorta (extending from aortic arch to aortic bifurcation and included adventitia but stripped of adherent fat and connective tissue), brain (whole brain), pituitary (including both anterior and neurointermediate lobes), spinal cord (extending from cervical region to the cauda equina), and mesentery. The portion of mesentery used in these studies represented that adjacent to the small intestine and contained a rich arcade of blood vessels. Although this tissue is composed primarily of adipose tissue and also contains lymphatics, it was chosen for its relatively high abundance of medium to small vessels.

RNA was extracted from tissues using guanidine thiocyanate (28). $20 \mu \mathrm{g}$ anglerfish islet RNA were added to each tissue homogenate so as to provide a measure of mRNA recovery. The yield of total RNA was determined from the absorbance at $260 \mathrm{~nm}$. After glyoxylation, RNA was electrophoresed on $1.5 \%$ agarose gels. The positions of $28 \mathrm{~s}$ and $18 \mathrm{~s}$ ribosomal RNA were determined by ultraviolet shadowing, and then RNA was transferred to a nylon membrane (29). The sequences of all synthetic oligonucleotides used in this study are given in the Appendix.

1. Abbreviations used in this paper: Dex, dexamethasone; $\mathrm{E}_{2}$, ethynylestradiol; $\mathrm{Nx}$, nephrectomized; $\mathrm{T}_{3}$, triiodothyronine. 
Angiotensinogen mRNA was hybridized with a mixture of eight synthetic oligonucleotides (ANG-2 to ANG-9) corresponding to all five exons of the rat angiotensinogen gene $(30,31)$. Simultaneously, anglerfish insulin mRNA (32) was hybridized with a 31 base oligonucleotide (FINS-1). Oligonucleotides were labeled with ${ }^{32} \mathrm{P}$ at the $5^{\prime}$ end, to a specific activity of $2,000-4,000 \mathrm{Ci} / \mathrm{mmol}$, using the forward reaction (33). For all hybridizations, the anglerfish insulin oligonucleotide was used at $1 \times 10^{6}$ $\mathrm{dpm} / \mathrm{ml}$; the angiotensinogen oligonucleotides were used at $4 \times 10^{5} \mathrm{dpm} /$ $\mathrm{ml}$ for hybridization of liver RNA, and $4 \times 10^{6} \mathrm{dpm} / \mathrm{ml}$ for hybridization of RNA extracted from all other tissues. The nylon membranes were prehybridized at $60^{\circ} \mathrm{C}$ for $16 \mathrm{~h}$ in $1 \mathrm{M}$ sodium chloride, $1 \%$ sodium dodecyl sulfate, $10 \%$ dextran sulfate, and then were hybridized at $60^{\circ} \mathrm{C}$ for $16 \mathrm{~h}$ in the same buffer containing the ${ }^{32} \mathrm{P}$-labeled oligonucleotides. The membranes were washed twice at room temperature in $0.3 \mathrm{M}$ sodium chloride, $0.03 \mathrm{M}$ sodium citrate, $\mathrm{pH} 7.0$, and then twice at $60^{\circ} \mathrm{C}$ in the same buffer containing $1 \%$ sodium dodecyl sulfate. For quantitation, the hybridization intensities were compared by densitometric scanning of autoradiographs in a linear response range. For each lane, the ratio of angiotensinogen to anglerfish insulin mRNA was calculated and then normalized with respect to the ratio for the standard RNA preparation (see below). By using this approach we were able to correct our estimates of angiotensinogen mRNA abundance for variation in recovery of mRNA through the extraction, and also for variation between experiments in the efficiency of hybridization. To estimate the variance between gels

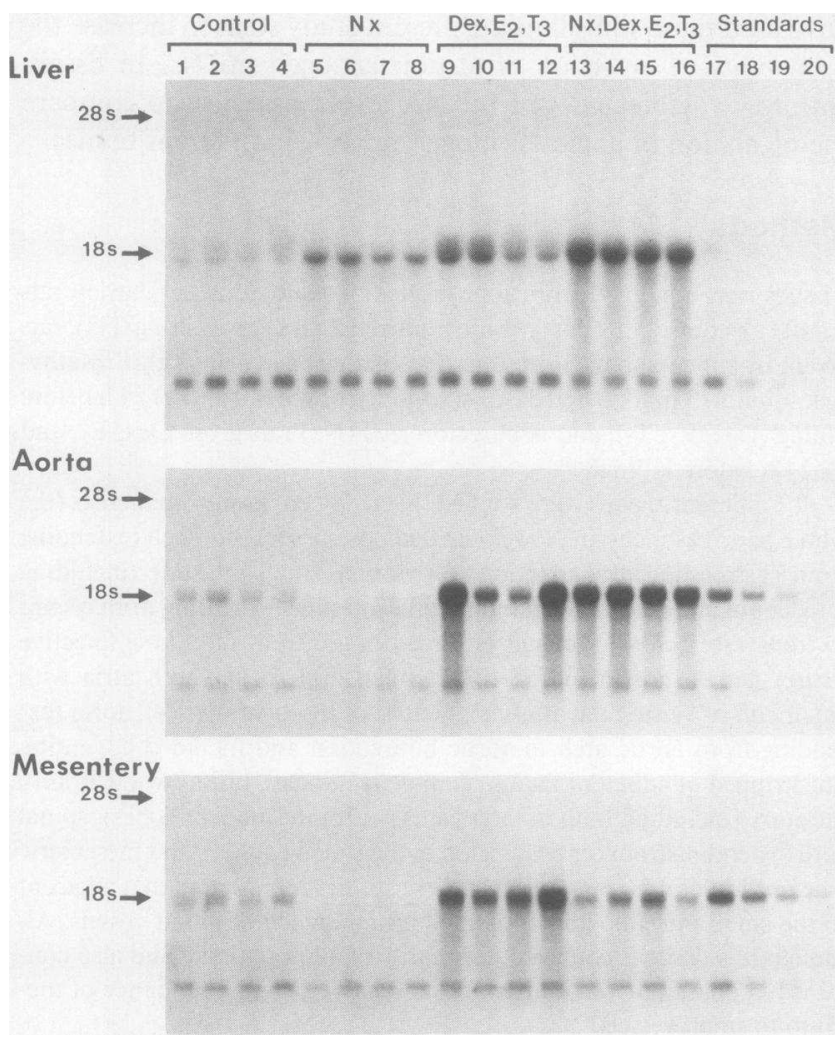

Figure 1. Autoradiographs of Northern blot analysis of RNA extracted from liver, aorta, and mesentery of control rats (lanes 1-4), $\mathrm{Nx}$ rats $(5-8)$, rats given Dex, $E_{2}$, and $T_{3}(9-12)$, and $N x$ rats given Dex, $E_{2}$, and $\mathrm{T}_{3}(13-16)$. Each blot was hybridized simultaneously with ${ }^{32} \mathrm{P}-\mathrm{la}-$ beled oligonucleotides specific for angiotensinogen mRNA $(\sim 2,000$ bases, migrating close to the position of $18 \mathrm{~s}$ ribosomal RNA) and the internal recovery marker anglerfish insulin mRNA ( 840 bases, shown in the lower part of each panel). Each of lanes 1-16 represents a separate rat. 17-20 represent the standard RNA preparation; for 17 , the amount of anglerfish insulin mRNA represents $100 \%$ recovery and 18-20 represent serial twofold dilutions of the standard RNA preparation. associated with this method of quantitation of angiotensinogen mRNA, the difference in the results of quantitation obtained for 19 samples, each run on two gels run on different days, was calculated and expressed as the percentage of the mean value for the two estimates. For two pairs of gels the mean difference was $31 \pm 28 \%$ (mean $\pm \mathrm{SD}, n=19$ ).

Nuclease S1 protection assay of angiotensinogen mRNA was performed using a modification of the method of Favalora et al. (34). $20 \mu \mathrm{l}$ of RNA (containing 6-44 $\mu \mathrm{g}$ RNA) were hybridized with ${ }^{32} \mathrm{P}$-labeled synthetic oligonucleotides in a total volume of $30 \mu \mathrm{l} 400 \mathrm{mM}$ sodium chloride, $40 \mathrm{mM}$ piperazine- $N, N^{1}$-bis[2-ethanesulfonic acid], $1 \mathrm{mM}$ ethylenediaminetetraacetic acid, $1 \%$ sodium dodecyl sulfate, $\mathrm{pH} 6.4$, and covered with $50 \mu \mathrm{l}$ paraffin oil. For nuclease S1 protection assay of RNA prepared from aorta, mesentery, atria, brain, spinal cord, large intestine, adrenal, and kidney, a single ${ }^{32}$ P-labeled oligonucleotide, RANG-3, was used. For all other tissues, a mixture of three ${ }^{32} \mathrm{P}$-labeled oligonucleotides, each 40 bases in length, was used. These three oligonucleotides, RANG3, RANG-4, and RANG-5, were complementary to angiotensinogen mRNA corresponding to the sites of introns 1,2 , and 3, respectively, of the angiotensinogen gene. After heating at $85^{\circ} \mathrm{C}$ for $15 \mathrm{~min}$, hybridization was performed at $60^{\circ} \mathrm{C}$ for $48 \mathrm{~h}$. Digestion with nuclease $\mathrm{S} 1$ (64 U in $300 \mu \mathrm{l} 300 \mathrm{mM}$ sodium chloride, $30 \mathrm{mM}$ sodium acetate, $3 \mathrm{mM}$ zinc acetate, $\mathrm{pH} 4.74$, containing $15 \mu \mathrm{g}$ salmon sperm DNA) was performed at $30^{\circ} \mathrm{C}$ for $60 \mathrm{~min}$. After addition of $50 \mu \mathrm{l}$ termination buffer $(4 \mathrm{M}$ ammonium acetate, $100 \mathrm{mM}$ ethylenediaminetetraacetic acid), the mixture was extracted with phenol-chloroform, ethanol precipitated, electrophoresed on a $20 \%$ acrylamide gel containing $8 \mathrm{M}$ urea, and the dried gel subjected to autoradiography.

Each Northern blot and nuclease S1 protection assay included serial twofold dilutions of a standard RNA preparation. This standard RNA preparation contained $100 \mu \mathrm{g} / \mathrm{ml}$ liver RNA from a Nx, Dex, $E_{2}, T_{3}$ rat and $100 \mu \mathrm{g} / \mathrm{ml}$ anglerfish islet RNA in $1 \mathrm{mg} / \mathrm{ml} E$. coli ribosomal RNA, and dilutions were performed in $E$. coli ribosomal RNA $(1 \mathrm{mg} / \mathrm{ml})$. For the Northern blots the highest standard was $7.4 \mu \mathrm{l}$ of this standard RNA preparation $(0.74 \mu \mathrm{g}$ each of liver and anglerfish islet RNA). For the nuclease S1 protection experiments, the highest standard was $20 \mu \mathrm{l}$ of an eightfold dilution of the standard RNA preparation $(0.25 \mu \mathrm{g}$ liver RNA). Each nuclease $S 1$ protection assay also included four blank samples containing $20 \mu \mathrm{l} E$. coli ribosomal RNA $(1 \mathrm{mg} / \mathrm{ml})$.

The statistical significance of differences between treatment groups and the control was determined by Mann-Whitney U test (35).

\section{Results}

Northern blot analysis demonstrated angiotensinogen mRNA in RNA extracted from liver, aorta, mesentery, atria, kidney, brain, spinal cord, large intestine, adrenal, and lung (Figs. 1-6). For all tissues, the electrophoretic migration of angiotensinogen mRNA was indistinguishable from that of liver, migrating close to the position of $18 \mathrm{~s}$ ribosomal RNA ( $\sim 2,000$ bases). Anglerfish insulin mRNA ( 840 bases) was well separated from angiotensinogen mRNA, and the two were easily quantitated by densitometric scanning of the autoradiographs. For Northern blot analysis of liver RNA (Fig. 1, upper panel), the intensity of hybridization of the angiotensinogen mRNA of the standards was much less than shown in the other autoradiographs because only one-tenth the amount of angiotensinogen mRNA-specific ${ }^{32} \mathrm{P}$ labeled oligonucleotides was used for hybridization, given the high levels of angiotensinogen mRNA in liver.

As shown in Fig. 6, the levels of angiotensinogen mRNA in lung were close to the limit of detection by Northern blot analysis. To confirm this result, a nuclease S1 protection assay was performed that clearly demonstrated angiotensinogen mRNA in lung (Fig. 7). Similarly, for aorta, mesentery, atria, brain, spinal cord, large intestine, adrenal, and kidney, the presence of angiotensinogen mRNA was confirmed by nuclease S1 protection assay (Fig. 8). 
Atria

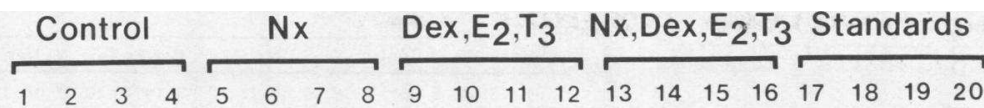

$28 s \rightarrow$

$18 \mathrm{~s} \rightarrow$

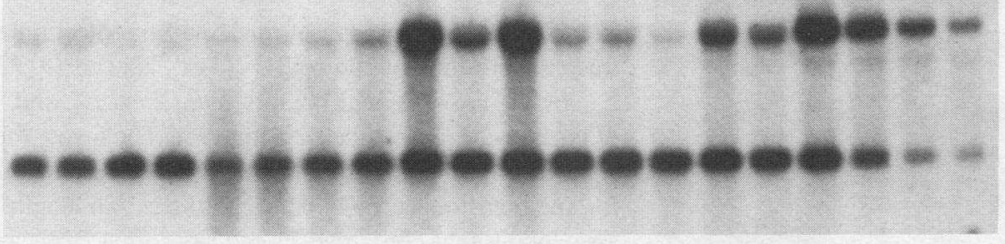

\section{Ventricles}

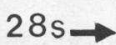

$18 s \rightarrow$

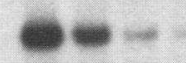

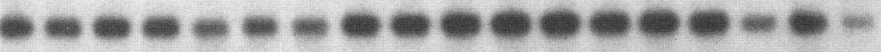

Figure 2. Autoradiographs of Northern blot analysis of RNA extracted from atria and ventricles. For explanation, see legend to Fig. 1.
Angiotensinogen mRNA was also evident on Northern blot analysis of RNA extracted from spleen and stomach, but the levels were too low for accurate quantitation (data not shown). Moreover, ultraviolet shadowing of the electrophoresed splenic RNA showed some degradation of ribosomal RNA, particularly for rats given Dex, $E_{2}$, and $T_{3}$, presumably due to the lymphocytolytic effect of Dex. The nuclease $S 1$ protection assay confirmed the presence of angiotensinogen mRNA in spleen and stomach (Fig. 9). Fig. 9 also shows ventricle, pituitary, small intestine, pancreas, and testes to be clearly negative for angio-
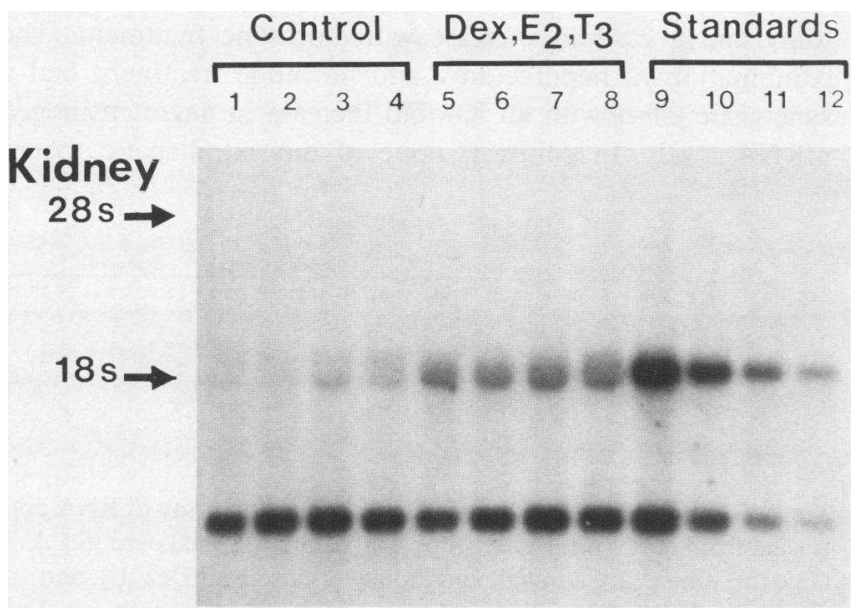

Figure 3. Autoradiograph of Northern blot analysis of RNA extracted from kidney of control rats (lanes 1-4) and rats given Dex, $E_{2}$, and $T_{3}$ (5-8). 9-12 represent the standard RNA preparation; for 9, the amount of anglerfish insulin mRNA represents $100 \%$ recovery and 10-12 represent serial twofold dilutions of the standard RNA preparation. Further explanation is given in legend to Fig. 1. tensinogen mRNA, in agreement with the results of Northern blot analysis (Figs. 2, 4, 5, and data not shown).

The nuclease S1 protection assay provided estimates of angiotensinogen mRNA abundance that were in close agreement
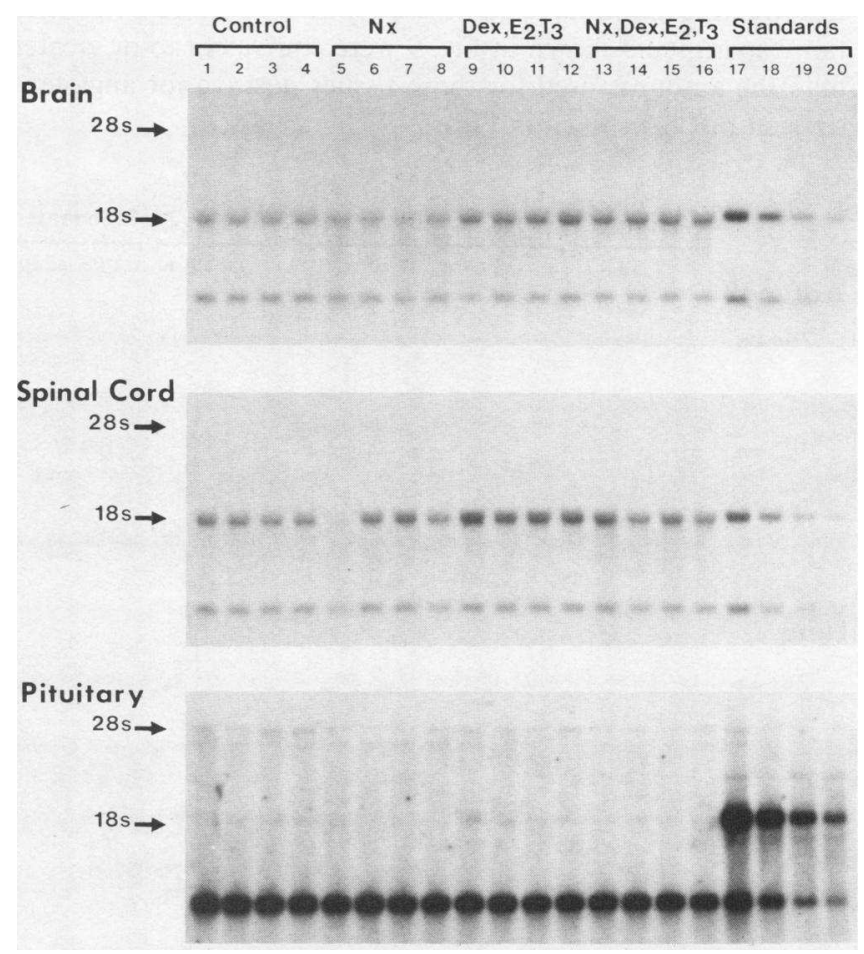

Figure 4. Autoradiographs of Northern blot analysis of RNA extracted from brain, spinal cord, and pituitary. For explanation, see legend to Fig. 1 . 


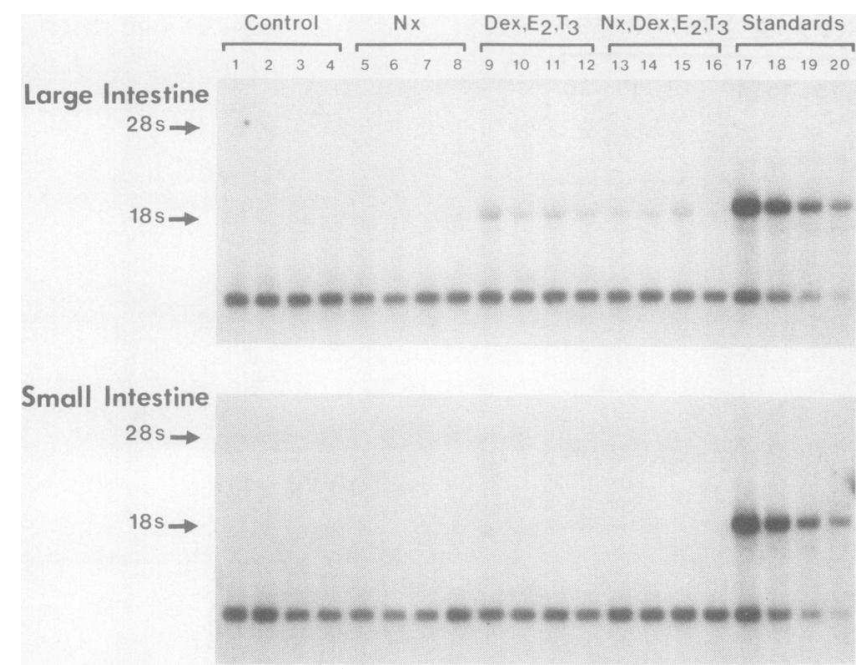

Figure 5. Autoradiographs of Northern blot analysis of RNA extracted from large intestine and small intestine. For explanation, see legend to Fig. 1.

with the results of Northern blot analysis, thus providing unequivocal confirmation of our identification of angiotensinogen mRNA in these 11 extrahepatic tissues. Figs. 7 and 9 show fragments of the ${ }^{32} \mathrm{P}$-labeled oligonucleotides migrating below the position of the intact probe in the lanes of the blank and standards. This represented partial (less than full length) protection of one of the oligonucleotides (RANG-4) by a component of the E. coli ribosomal RNA (data not shown). This was not seen in the experiment shown in Fig. 8, where only one ${ }^{32} \mathrm{P}$-labeled oligonucleotide (RANG-3) was used. For testes, ventricles, pancreas, and small intestine (tissues negative for angiotensinogen mRNA), the amounts of RNA used for the nuclease S1 protection experiments shown in Fig. 9 were equivalent to or greater than the amounts used for those tissues positive for angiotensinogen mRNA shown in Figs. 7-9.

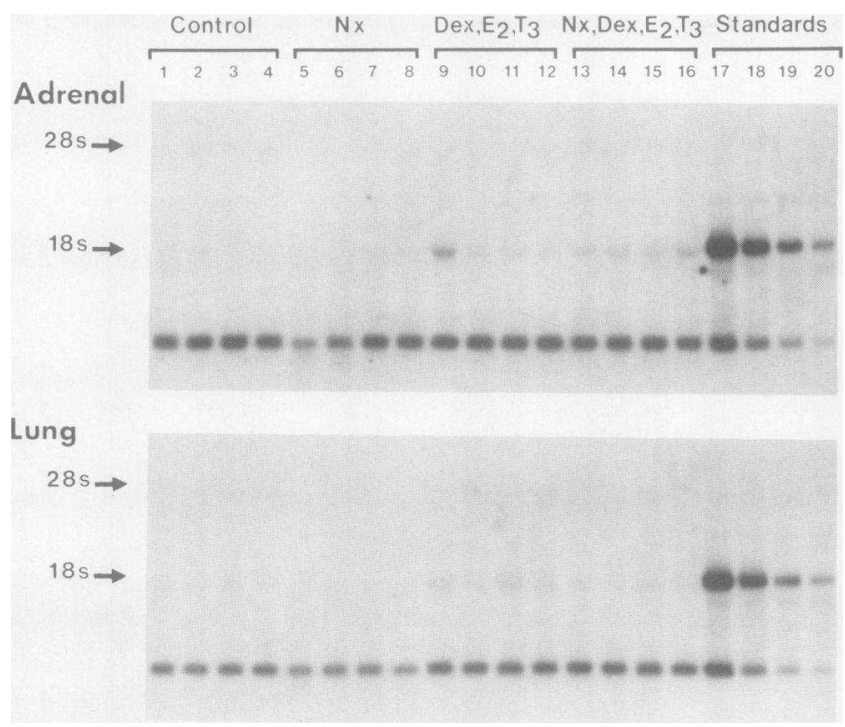

Figure 6. Autoradiographs of Northern blot analysis of RNA extracted from adrenal and lung. For explanation, see legend to Fig. 1.

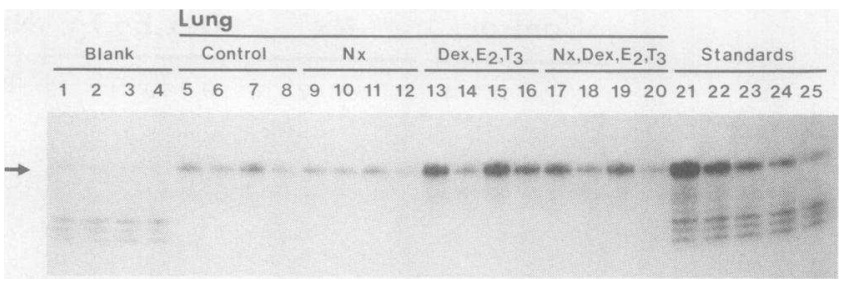

Figure 7. Autoradiograph of nuclease $\mathrm{S} 1$ protection assay of RNA extracted from lung of control rats $(5-8)$, Nx rats $(9-12)$, rats given Dex, $E_{2}$, and $T_{3}(13-16)$, and $N x$ rats given Dex, $E_{2}$, and $T_{3}(17-20)$. Each of lanes 5-20 represents a separate rat. The arrow indicates full length protection of the mixture of three ${ }^{32} \mathrm{P}$-labeled oligonucleotides specific for angiotensinogen mRNA, each 40 bases in length. 1-4 represent the assay blank that contained $E$. coli ribosomal RNA and 21-25 represent serial twofold dilutions (in E. coli ribosomal RNA) of a standard RNA preparation (see Methods).

The levels of total RNA and angiotensinogen mRNA in the 17 different tissues are shown in Table I. For those tissues where angiotensinogen mRNA abundance was determined from Northern blot analysis, the values shown have been corrected for mRNA recovery as described in Methods. When expressed per gram tissue wet weight, the levels of angiotensinogen mRNA in extrahepatic tissues of control rats were $<4 \%$ of that of liver (Table I). However, most extrahepatic tissues had levels of total RNA less than that of liver. When expressed per milligram total RNA, the levels of angiotensinogen mRNA of brain, spinal cord, aorta, and mesentery were $26-42 \%$ of that of liver. The data for total RNA shown in Table I have not been corrected for the recovery of anglerfish insulin mRNA. Recoveries of $25 \%$ or greater were associated with similar levels of total RNA, suggesting that the major cause of low recoveries was partial degradation of mRNA, rather than losses of RNA. Where recoveries were $12.5 \%$ or less, the levels of total RNA were also low, and these data were not included in Table I.

Comparison of the effects of nephrectomy and hormone treatment showed tissue-specific differences in the regulation of angiotensinogen mRNA levels (Fig. 10). Liver angiotensinogen mRNA levels showed a 2.1-fold increase with bilateral nephrectomy and a 2.8 -fold increase with hormone treatment. The combination of nephrectomy and hormone treatment had a synergistic effect with an 8.8-fold increase in angiotensinogen mRNA levels. In contrast, none of the extrahepatic tissues

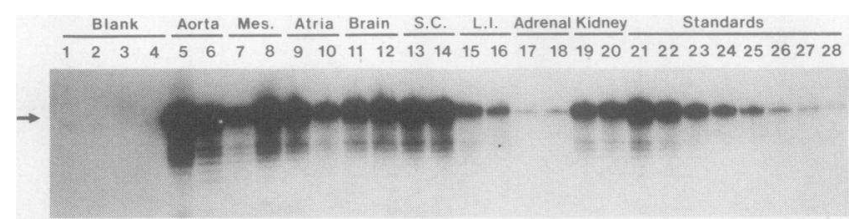

Figure 8. Autoradiograph of nuclease $\mathbf{1} 1$ protection assay of RNA extracted from aorta, mesentary (Mes.), atria, brain, spinal cord (S.C.), large intestine (L.I.), adrenal, and kidney of rats given Dex, $E_{2}$, and $T_{3}$. Each of the two lanes for each tissue represents a separate rat. The arrow indicates full length protection of the ${ }^{32} \mathrm{P}$-labeled oligonucleotide specific for angiotensinogen mRNA, RANG-3. 1-4 represent the assay blank which contained $E$. coli ribosomal RNA and 21-28 represent serial twofold dilutions (in $E$. coli ribosomal RNA) of a standard RNA preparation (see Methods). 


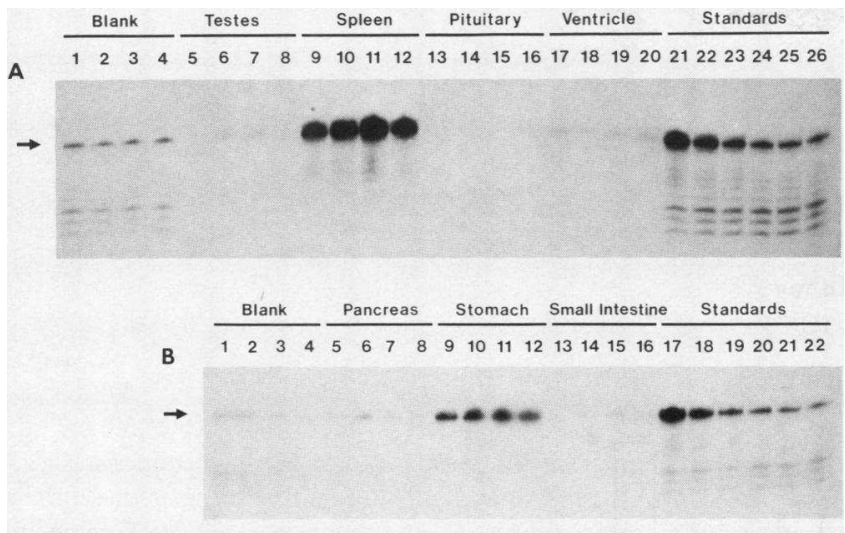

Figure 9. (A) Autoradiograph of nuclease S1 protection assay of RNA extracted from testes (lanes 5-8), spleen (9-12), pituitary (13-16), and ventricles $(17-20)$ of rats given Dex, $E_{2}$, and $T_{3}$. Each of the four lanes for each tissue represents a separate rat. The arrow indicates full length protection of the mixture of three ${ }^{32} \mathrm{P}$-labeled oligonucleotides specific for angiotensinogen mRNA, each 40 bases in length. 1-4 represent the assay blank which contained $E$. coli ribosomal RNA and 21-26 represent serial twofold dilutions (in $E$. coli ribosomal RNA) of a standard RNA preparation (see Methods). (B) Autoradiograph of nuclease $S 1$ protection assay of RNA extracted from pancreas $(5-8)$, stomach (9-12), and small intestine (13-16) of rats given Dex, $E_{2}$, and $T_{3}$. Each of the four lanes for each tissue represents a separate rat. The arrow indicates full length protection of the mixture of three ${ }^{32} \mathrm{P}$-labeled oligonucleotides specific for angiotensinogen mRNA, each 40 bases in length. 1-4 represent the assay blank which contained $E$. coli ribosomal RNA and 17-22 represent serial twofold dilutions (in $E$. coli ribosomal RNA) of a standard RNA preparation (see Methods).

showed an increase in angiotensinogen mRNA levels after nephrectomy. Whereas brain, spinal cord, atria, and large intestine showed no change, aorta, mesentery, adrenal, and lung showed significant decreases in angiotensinogen mRNA levels after nephrectomy. All extrahepatic tissues showed increases in angiotensinogen mRNA levels after hormone treatment. For brain, spinal cord, lung, and adrenal, these increases were small (61, 69,49 , and $40 \%$, respectively) and were not statistically significant for spinal cord and lung. However, the increases for kidney (3.1fold), aorta (5.6-fold), mesentery (4.6-fold), atria (5.1-fold), and large intestine (8-fold) were equal to or greater than that shown by liver with hormone treatment. None of the extrahepatic tissues showed the synergistic effect of nephrectomy and hormone treatment on angiotensinogen mRNA levels shown by liver. Whereas brain, spinal cord, aorta, adrenal, and lung showed equivalent responses to hormone treatment and hormone treatment combined with nephrectomy, for mesentery, atria, and large intestine, the combination caused elevations in angiotensinogen mRNA levels that were only half those seen for hormone treatment alone.

\section{Discussion}

The present results demonstrate that the angiotensinogen gene is expressed in multiple tissues of the rat and provide evidence that in each of these tissues a local angiotensin system may operate that is independent of the circulating renin-angiotensin system. For all tissues containing angiotensinogen mRNA, its size, as shown by electrophoretic migration, was indistinguishable from that of liver. This suggests that angiotensinogen mRNA of extrahepatic tissues codes for an angiotensinogen precursor very similar to, if not identical to that of liver. For brain, this result is confirmation of previous studies using cell-free translation (26).

In each tissue, angiotensinogen mRNA was identified by both Northern blot analysis and nuclease $\mathrm{S} 1$ protection assay. Given that these two methods gave similar quantitative estimates of angiotensinogen mRNA abundance in each tissue (relative to the standard liver RNA preparation), they provide a definitive identification of angiotensinogen mRNA in these tissues. The use of the internal recovery marker (anglerfish insulin mRNA) allowed us to accurately quantitate angiotensinogen mRNA levels over a wide range ( $>1,000$-fold). Moreover, the use of the nuclease S1 protection assay increased the sensitivity of detection of angiotensinogen mRNA by another order of magnitude. Given that angiotensinogen mRNA of liver of $\mathrm{Nx}$ rats given hormone treatment is $\sim 1 \%$ of $\mathrm{mRNA}$ abundance (25), the nuclease $\mathrm{S} 1$

Table I. Total RNA and Angiotensinogen $m R N A$ Contents of Different Tissues Obtained from Control Rats

\begin{tabular}{|c|c|c|c|}
\hline \multirow[t]{2}{*}{ Tissue } & \multirow{2}{*}{$\begin{array}{l}\text { Total RNA } \\
m g / g \text { tissue wet wt }\end{array}$} & \multicolumn{2}{|c|}{ Angiotensinogen mRNA } \\
\hline & & $m U / g$ tissue wet $w t$ & $m U / m g$ total $R N A$ \\
\hline \multirow[t]{2}{*}{ Liver } & $6.21 \pm 0.24(8)$ & $1,000 \pm 100(8)$ & $166 \pm 22(8)$ \\
\hline & $0.75 \pm 0.02$ & & \\
\hline Brain & $(10)$ & $32 \pm 3(10)$ & $43 \pm 5(10)$ \\
\hline Spinal cord & $0.28 \pm 0.03(6)$ & $19 \pm 3(6)$ & $70 \pm 8(6)$ \\
\hline Aorta & $0.41 \pm 0.03(4)$ & $22 \pm 3(4)$ & $55 \pm 10(4)$ \\
\hline Mesentery & $0.42 \pm 0.15(6)$ & $16 \pm 2(6)$ & $66 \pm 19(6)$ \\
\hline Kidney & $2.39 \pm 0.16(4)$ & $16 \pm 5(4)$ & $7.0 \pm 2.4(4)$ \\
\hline Adrenal & $2.2 \pm 0.3(9)$ & $11 \pm 4(12)$ & $3.8 \pm 0.9(9)$ \\
\hline Atria & $0.75 \pm 0.03(4)$ & $5.0 \pm 1.6(5)$ & $4.8 \pm 1.2(4)$ \\
\hline Lung & $1.65 \pm 0.07(4)$ & $2.6 \pm 0.5(4)$ & $1.6 \pm 0.3(4)$ \\
\hline Large intestine & $2.20 \pm 0.27(4)$ & $0.90 \pm 0.08(4)$ & $0.43 \pm 0.07(4)$ \\
\hline Spleen & $3.26 \pm 0.54(4)$ & $20-40^{*}$ & $10-20^{*}$ \\
\hline Stomach & $2.51 \pm 0.18(4)$ & $5-11^{*}$ & $2.5-5.0^{*}$ \\
\hline Pancreas & $10.92 \pm 0.98(6)$ & $<2.5^{*}$ & $<0.5^{*}$ \\
\hline Small intestine & $4.51 \pm 0.89$ & $<1.4^{*}$ & $<0.2^{*}$ \\
\hline Testes & $2.03 \pm 0.08$ & $<0.7^{*}$ & $<0.3^{*}$ \\
\hline Ventricles & $0.98 \pm 0.03(4)$ & $<0.2^{*}$ & $<0.2^{*}$ \\
\hline Pituitary & $\ddagger$ & $\ddagger$ & $<1^{*}$ \\
\hline
\end{tabular}

For angiotensinogen mRNA levels, $1 \mathrm{U}$ represents the amount of angiotensinogen mRNA per gram of liver of control rats (mean of eight rats). Data are presented as mean $\pm S E$, with the number of rats in parentheses. All data represent control rats, and angiotensinogen mRNA levels were estimated by Northern blot analysis, except where indicated otherwise. Estimates of angiotensinogen mRNA levels from Northern blot analyses are corrected for mRNA recovery as described in Methods. The data for total RNA are not corrected for recovery (see Results).

* Estimate derived from nuclease $\mathrm{S} 1$ protection assay of RNA prepared from tissues of rats given Dex, $E_{2}$, and $T_{3}$. $\ddagger$ Pituitary glands were not weighed. For control rats, the total RNA content was $62 \pm 4$ (mean $\pm \mathrm{SE}, n=10) \mu \mathrm{g} /$ pituitary. For rats given Dex, $E_{2}$, and $T_{3}$, angiotensinogen mRNA levels were calculated to be $<0.06 \mathrm{mU} /$ pituitary. 


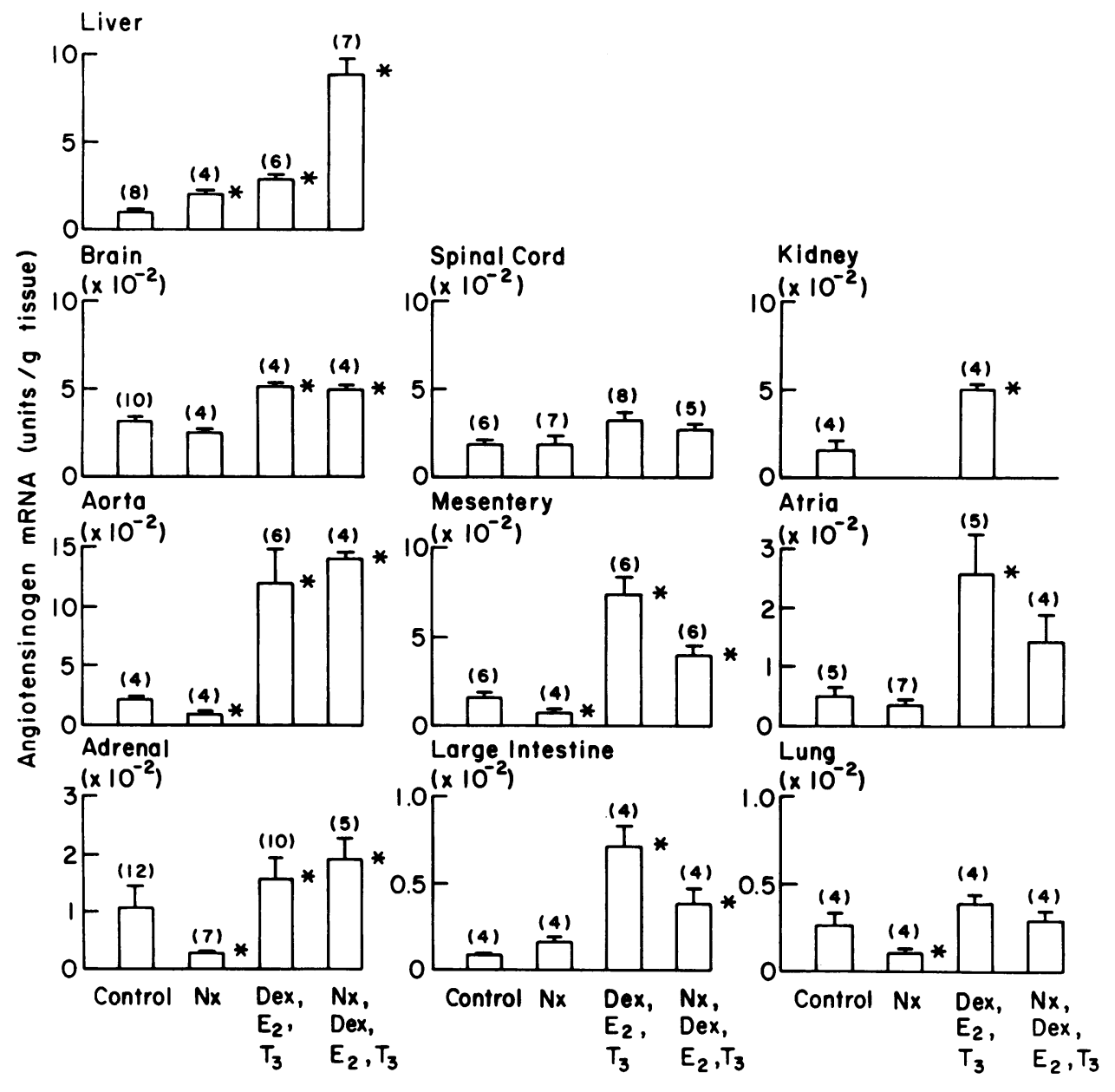

Figure 10. Quantitation and tissuespecific regulation of angiotensinogen mRNA levels of control rats, $\mathrm{Nx}$ rats, rats given Dex, $E_{2}$, and $T_{3}$, and $N x$ rats given Dex, $E_{2}$, and $T_{3}$. Angiotensinogen mRNA levels (mean $\pm \mathrm{SE}$, number of rats in parentheses) are expressed as units per gram wet weight of tissue, where $1 \mathrm{U}$ is the amount of angiotensinogen mRNA per gram of liver of control rats (mean of eight rats). These estimates of angiotensinogen mRNA abundance were determined from Northern blot analyses and have been corrected for recovery of mRNA as described in Methods. Note that for all tissues except liver, the ordinate is expanded 100 -fold. ${ }^{*} P<0.05$ compared with control. protection assay of angiotensinogen mRNA has a sensitivity in the order of $1 / 10^{6} \mathrm{mRNA}$ molecules; i.e., $<1 \mathrm{mRNA}$ molecule per cell. This high sensitivity of the nuclease $\mathrm{S} 1$ protection assay reflects several factors including $(a)$ the use of larger amounts of RNA than Northern blot analysis, $(b)$ the greater efficiency of hybridization in solution, $(c)$ the greater resolution of thin acrylamide gels, with lower background, and $(d)$ that the nuclease S1 protection assay is able to detect partially degraded mRNA that would not be detected by Northern blot analysis.

The sensitivity of our methodology has enabled us to detect low levels of angiotensinogen mRNA in tissues in which only a small proportion of cells may express the angiotensinogen gene. Given that extrahepatic tissues have a much greater cellular heterogeneity than liver, our data suggest that for the subpopulation of cells containing angiotensinogen mRNA in each tissue, the abundance of angiotensinogen mRNA per cell may be equal to or higher than that of hepatocytes. Since the total RNA content of a tissue is an index of the rate of protein synthesis in the tissue, expression of angiotensinogen mRNA per milligram total RNA provides an index of the proportion of $m R N A$ in a tissue that is angiotensinogen mRNA. When angiotensinogen mRNA is expressed per milligram total RNA (Table I), extrahepatic tissues positive for angiotensinogen mRNA can be divided into two groups: (a) brain, spinal cord, aorta, and mesentery, with angiotensinogen mRNA levels $26-42 \%$ of that of liver, and $(b)$ kidney, adrenal, atria, lung, large intestine, spleen, and stomach, with much lower levels of angiotensinogen mRNA. These quan- titative estimates suggest that in the latter group, angiotensinogen mRNA may be present in vascular and/or neural components of each tissue. Furthermore, the response of each tissue mRNA level to hormone treatment (Fig. 10) was one of two categories: (a) those tissues with $40-70 \%$ increase, suggesting a neural pattern of regulation, and $(b)$ those tissues with a three- to eightfold increase, suggesting a vascular pattern of regulation. At present, we can only speculate as to which particular cells within each tissue express the angiotensinogen gene. We are currently investigating this matter. Moreover, our data are confined to angiotensinogen mRNA abundance, and its relation to the level of angiotensinogen synthesis in each tissue will require further studies. Given our finding of angiotensinogen $\mathrm{mRNA}$ in vascular tissue, one might expect to find angiotensinogen mRNA in all vascularized tissues. Our failure to detect angiotensinogen mRNA in some tissues may represent differences in tissue vascularization, and also a regional specificity in vascular angiotensinogen gene expression.

The present data clearly demonstrate that bilateral nephrectomy and hormone treatment modify angiotensinogen gene expression by different mechanisms. The differences between tissues in angiotensinogen gene expression reflect either differences in regulation of angiotensinogen gene transcription and/ or mRNA stability, and will provide a valuable model for the study of the mechanisms of tissue-specific gene expression. The difference between liver and extrahepatic tissues in angiotensinogen mRNA response to bilateral nephrectomy (Fig. 10) indi- 
cates a major difference in regulation of angiotensinogen mRNA levels. The mechanism by which nephrectomy causes an increase in liver angiotensinogen production is not known. Whereas some authors have suggested the role of a stimulatory agent present in plasma after nephrectomy (36), other authors suggest that hepatic angiotensinogen production is subject to tonic inhibition by renin, which may be either a direct effect or mediated indirectly via plasma levels of des-angiotensin I-angiotensinogen (37). Aorta, mesentery, adrenal, and lung showed significant decreases in angiotensinogen mRNA levels after nephrectomy. These decreases may have been due to changes in RNA metabolism similar to those described for uremic rat liver (38), where elevated levels of ribonuclease in the cytosol are accompanied by degradation of albumin mRNA sequences associated with membrane bound polysomes. Note that use of the anglerfish insulin mRNA as recovery marker could not correct for degradation of angiotensinogen mRNA before and during homogenization of the tissue in guanidine thiocyanate.

Definition of the role of angiotensinogen gene expression in extrahepatic tissues must await identification of the specific cells which contain angiotensinogen mRNA. Local tissue angiotensinogen synthesis may contribute to either intracellular or extracellular angiotensin production, and such local angiotensin production, by a mechanism independent of the circulating renin-angiotensin system, may have important physiological and pathogenic roles. The relatively high level of angiotensinogen mRNA in brain and spinal cord is in agreement with studies of the distribution of angiotensinogen in brain (39-43) which, together with immunohistochemical studies of angiotensin-like immunoreactivity $(44,45)$, suggest that angiotensinogen gene expression is widespread in the brain and spinal cord.

Many studies suggest the generation of angiotensin in vasculature by a mechanism independent of the circulating reninangiotensin system (10). Studies of vascular angiotensinogen and reninlike activity have been unable to exclude plasma as their source $(46,47)$. Re et al. (48) and Lilly et al. (49) have provided evidence for the synthesis of renin by vascular smooth muscle and endothelial cells in vitro. However, given that in the rat, aortic reninlike activity falls to very low levels after nephrectomy $(50,51)$, local synthesis would appear to make little contribution to vascular reninlike activity in vivo. In contrast, the present demonstration of relatively high levels of angiotensinogen mRNA in aorta and mesentery in vivo provides direct evidence for a local vascular angiotensin system that is independent of the circulating renin-angiotensin system.

There is much evidence in support of a role for local angiotensin production in the regulation of renal function $(6-8,52-$ 55). Studies of the isolated perfused kidney indicate a dominant role for plasma angiotensinogen in intrarenal generation of angiotensin (56). Our present data also indicate a role for intrarenal synthesis of angiotensinogen. The level of angiotensinogen mRNA in kidney and its response to hormone treatment are consistent with a vascular site of angiotensinogen gene expression. The studies of Morris and Johnson (55) suggest that the juxtaglomerular apparatus may synthesize angiotensinogen, although immunohistochemical studies have not provided any confirmation $(54,57)$.

For the adrenal, there is evidence for both synthesis of renin and local angiotensin formation (58-61), which may contribute to regulation of the zona glomerulosa or the medulla (4). The significance of our identification of angiotensinogen mRNA in the adrenal must await cellular localization. However, the re- sponse of adrenal angiotensinogen mRNA levels to hormone treatment does suggest a neural pattern of response.

The finding of angiotensinogen mRNA in atria suggests a role for local angiotensin generation in the regulation of cardiac function (4). Recently Dzau et al. (62) have described the presence of renin mRNA in mouse heart and Nieuwenhuis and Theron (63) have reported that rat atria contain a pressor substance with properties characteristic of angiotensin. Our finding of angiotensinogen mRNA in lung is of interest since a recent analysis of angiotensin metabolism suggested that the pulmonary circulation is an important site for the generation of angiotensin I (10). However, the levels of lung angiotensinogen mRNA were low, and the response to hormone treatment suggests a neural, rather than vascular, pattern of response.

Immunohistochemical studies of the gastrointestinal tract have shown that ganglion cells within Auerbach's plexus contain strong angiotensin II-like immunoreactivity (44). These cells were observed in the colon and stomach, but were most abundant in the duodenum. However, we were unable to detect angiotensinogen mRNA in the small intestine. The significance of this result is unclear, since the response of angiotensinogen mRNA levels of the large intestine to hormone treatment resembled the vascular response, suggesting that neural elements may not be the major site of angiotensinogen gene expression in the gut.

The significance of our finding of angiotensinogen mRNA in the spleen must await further studies. Swales et al. (64) have reported that splenic arteries take up renin from plasma, where it is located predominantly in the media. Moreover, neutrophils contain cathepsin G, a neutral protease that is able to cleave angiotensinogen to produce angiotensin II directly (18), and also able to convert angiotensin I to angiotensin II (65). Thus angiotensinogen gene expression in the spleen may relate to vascular, neutrophil, or other cell function, which we hope to define by identification of the cell type that contains angiotensinogen mRNA.

In the present study, small intestine, pancreas, ventricles, testes, and pituitary were negative for angiotensinogen mRNA. This negative result for testes and pituitary is of interest since for both tissues there is evidence for synthesis of renin and local production of angiotensin $(44,61,66-69)$. Presumably for these two tissues, plasma is the source of angiotensinogen for local angiotensin production.

In conclusion, we have quantitated angiotensinogen mRNA in 17 different tissues of the rat. The levels of angiotensinogen mRNA in brain, spinal cord, aorta, and mesentery were similar to hepatic levels (when expressed per milligram total RNA), whereas the levels were much lower in kidney, adrenal, atria, lung, large intestine, spleen, and stomach. Small intestine, pancreas, ventricles, testes, and pituitary were negative for angiotensinogen mRNA. We have also demonstrated that the regulation of angiotensinogen mRNA levels is tissue specific. These results indicate that many of the tissue-specific actions of angiotensin may be mediated, at least in part, by local tissue angiotensin systems that are independent of the circulating reninangiotensin system. Such local tissue angiotensin systems may play an important role in many aspects of neural, vascular, renal, adrenal, cardiac, pulmonary, splenic, and intestinal function. Moreover, the modulation of vascular, cardiac, and renal angiotensinogen gene expression by hormone treatment emphasizes the potential pathogenic role of local tissue angiotensin systems in estrogenic, glucocorticoid-induced, and other forms of hypertension. 


\section{Appendix}

Sequences of oligonucleotide probes (shown $3^{\prime}$ to $5^{\prime}$ )

ANG-2 TATCGACACGAACAGACCCGACCTCGATTTC

ANG-3 TCTTGGGGTCACACCTCTGCGAGGGTCTCGGTTGGAAA

ANG-4 GCGTACATGTTCTACGACTCACTCCGTTCTCCACATCGGTCAC

ANG-5 AGAGAAAGATGGAACCTAGCAACCTAG

ANG-6 CGTGACCTCACTGCGGGTCTTGTTGAAGA

ANG-7 GGTCACGCGGAGTCTAGAGCTGTCCCACCT

ANG-8 CCGAGTCCGGTTCGACAGATGGGAAAACC

ANG-9 GTCGGGTGTCTCAGACGGGTCGTCG

RANG-3 CCTCGATTTCCTGTGTGTCTTCGTTCAGGTGTCTAGGCAC

RANG-4 GTGAAGGTTCCCTTGTACTCTCCGAAGAGGGTCGACTGAC

RANG-5 GCGGAGGAGCCCGGTAGGCAGACTGGGACGGCGTCGACCT

FINS-1 CAGACACCTCTGTCTCCAAAGAAGATGTTG.

\section{Acknowledgments}

We thank Chon Vo for the synthesis of the oligonucleotides and Janice Canniff for typing the manuscript.

These studies were supported in part by National Institutes of Health grant AM 34219. Dr. Campbell is the recipient of a C. J. Martin Fellowship from the National Health and Medical Research Council of Australia.

\section{References}

1. Blumberg, A. L., S. E. Denny, G. R. Marshall, and P. Needleman. 1977. Blood vessel-hormone interactions: angiotensin, bradykinin, and prostaglandins. Am. J. Physiol. 232:H305-H310.

2. Gunther, S., M. A. Gimbrone, Jr, and R. W. Alexander. 1980. Regulation by angiotensin II of its receptors in resistance blood vessels. Nature (Lond.). 287:230-232.

3. Fernandez, L. A., J. Twickler, and A. Mead. 1985. Neovascularization produced by angiotensin II. J. Lab. Clin. Med. 105:141-145.

4. Peach, M. J. 1977. Renin-angiotensin system: biochemistry and mechanisms of action. Physiol. Rev. 57:313-370.

5. Ganong, W. F. 1984. The brain renin-angiotensin system. Ann. Rev. Physiol. 46:17-31.

6. Levens, N. R., M. J. Peach, and R. M. Carey. 1981. Role of the intrarenal renin-angiotensin system in the control of renal function. Circ. Res. 48:157-167.

7. Mendelsohn, F. A. O. 1982. Angiotensin II: evidence for its role as an intra-renal hormone. Kidney Int. 22(Suppl. 12):S-78-S-81.

8. Navar, L. G., and L. Rosivall. 1984. Contribution of the reninangiotensin system to the control of intrarenal hemodynamics. Kidney Int. 25:857-868.

9. Levens, N. R. 1985. Control of intestinal absorption by the reninangiotensin system. Am. J. Physiol. 249(Gastrointest. Liver Physiol. 12): G3-G15.

10. Campbell, D. J. 1985. The site of angiotensin production. $J$. Hypertension. 3:199-207.

11. Deboben, A., T. Inagami, and D. Ganten. 1983. Tissue renin. In Hypertension. Second ed. J. Genest, O. Kuchel, P. Hamet, and M. Cantin, editors. McGraw Hill, Inc., New York. 194-209.

12. Haber, E., and E. E. Slater. 1977. Purification of renin. A review. Circ. Res. 40(Suppl. 1):I-36-I-40.

13. Menard, J., F-X. Galen, C. Devaux, N. Kopp, C. Auzan, and P. Corvol. 1980. Immunochemical differences between angiotensin Iforming enzymes in man. Clin. Sci. 59:41s-44s.

14. Dorer, F. E., K. E. Lentz, J. R. Kahn, M. Levine, and L. T. Skeggs. 1978. A comparison of the substrate specificities of cathepsin D and pseudorenin. J. Biol. Chem. 253:3140-3142.

15. Arakawa, K., M. Yuki, and M. Ikeda. 1980. Chemical identity of tryptensin with angiotensin. Biochem. J. 187:647-653.

16. Maruta, H., and K. Arakawa. 1983. Confirmation of direct angiotensin formation by kallikrein. Biochem. J. 213:193-200.

17. Franze de Fernandez, M. T., A. C. Paladini, and A. E. Delius.
1965. Isolation and identification of a pepsitensin. Biochem. J. 97:540546.

18. Tonnesen, M. G., M. S. Klempner, K. F. Austen, and B. U. Wintroub. 1982. Identification of a human neutrophil angiotensin IIgenerating protease as cathepsin G. J. Clin. Invest. 69:25-30.

19. Boucher, R., S. Demassieux, R. Garcia, and J. Genest. 1977. Tonin, angiotensin II system. A review. Circ. Res. 41(Suppl. 2):II-26II-29.

20. Husain, A., R. R. Smeby, D. Wilk, V. J. Dzau, and F. M. Bumpus. 1984. Biochemical and immunological properties of dog brain isorenin. Endocrinology. 114:2210-2215.

21. Haas, E., L. V. Lewis, P. Scipione, J. Koshy, A. U. Varde, and L. Renerts. 1984. Angiotensin-producing enzyme I of serum: formation by immunization with renin. J. Hypertension. 2:131-140.

22. Dzau, V. J., A. Brenner, N. Emmett, and E. Haber. 1980. Identification of renin and renin-like enzymes in rat brain by a renin-specific antibody. Clin. Sci. 59:45s-47s.

23.Nasjletti, A., and G. M. C. Masson. 1972. Studies on angiotensinogen formation in a liver perfusion system. Circ. Res. 30 and 31(Suppl. 2):II-187-II-202.

24. Clauser, E., J. Bouhnik, E. Coezy, P. Corvol, and J. Menard. 1983. Synthesis and release of immunoreactive angiotensinogen by rat liver slices. Endocrinology. 112:1188-1193.

25. Campbell, D. J., J. Bouhnik, E. Coezy, F. Pinet, E. Clauser, J. Menard, and P. Corvol. 1984. Characterization of precursor and secreted forms of rat angiotensinogen. Endocrinology. 114:776-785.

26. Campbell, D. J., J. Bouhnik, J. Menard, and P. Corvol. 1984. Identity of angiotensinogen precursors of rat brain and liver. Nature (Lond.). 308:206-208.

27. Skeggs, L. T., F. E. Dorer, J. R. Kahn, K. E. Lentz, and M. Levine. 1974. The biological production of angiotensin. In Angiotensin. Handbook of Experimental Pharmacology. I. H. Page and F. M. Bumpus, editors. Springer-Verlag, New York. 37:1-16.

28. Chirgwin, J. M., A. E. Przybyla, R. J. MacDonald, and W. J. Rutter. 1979. Isolation of biologically active ribonucleic acid from sources enriched in ribonuclease. Biochemistry. 18:5294-5299.

29. Thomas, P. S. 1983. Hybridization of denatured RNA transferred or dotted to nitrocellulose paper. Methods Enzymol. 100:255-266.

30. Ohkubo, H., R. Kageyama, M. Ujihara, T. Hirose, S. Inayama, and S. Nakanishi. 1983. Cloning and sequence analysis of cDNA for rat angiotensinogen. Proc. Natl. Acad. Sci. USA. 80:2196-2200.

31. Tanaka, T., H. Ohkubo, and S. Nakanishi. 1984. Common structural organization of the angiotensinogen and $\alpha_{1}$-antitrypsin genes. $J$. Biol. Chem. 259:8063-8065.

32. Hobart, P. M., L-P. Shen, R. Crawford, R. L. Pictet, and W. J. Rutter. 1980. Comparison of the nucleic acid sequence of anglerfish and mammalian insulin mRNAs from cloned cDNAs. Science (Wash. DC). 210:1360-1363

33. Maniatis, T., E. F. Fritsch, and J. Sambrook. 1982. Molecular Cloning. A Laboratory Manual. Cold Spring Harbor Laboratory, Cold Spring Harbor. 545 pp.

34. Favaloro, J., R. Treisman, and R. Kamen. 1980. Transcription maps of polyoma virus-specific RNA: analysis by two-dimensional nuclease S1 gel mapping. Methods Enzymol. 65:718-749.

35. Kirk, R. E. 1978. Introductory statistics. Brooks/Cole, Monterey. $438 \mathrm{pp}$.

36. Hasegawa, H., J. R. Shainoff, L. A. Lewis, and G. M. C. Masson. 1976. Further evidence for the existence of angiotensinogen stimulating activity (ASA) after nephrectomy. Proc. Soc. Exp. Biol. Med. 153:3743.

37. Herrmann, H. C., and V. J. Dzau. 1983. The feedback regulation of angiotensinogen production by components of the renin-angiotensin system. Circ. Res. 52:328-334.

38. Zern, M. A., S. H. Yap, R. K. Strair, G. A. Kaysen, and D. A. Shafritz. 1984. Effects of chronic renal failure on protein synthesis and albumin messenger ribonucleic acid in rat liver. J. Clin. Invest. 73:1 1671174 
39. Sernia, C., and I. A. Reid. 1980. Release of angiotensinogen by rat brain in vitro. Brain Res. 192:217-225.

40. Sernia, C., and M. D. Mowchanuk. 1983. Brain angiotensinogen: in vitro synthesis and chromatographic characterization. Brain Res. 259: 275-283.

41. Lewicki, J. A., J. H. Fallon, and M. P. Printz. 1978. Regional distribution of angiotensinogen in rat brain. Brain Res. 159:359-371.

42. Wallis, C. J., and M. P. Printz. 1980. Adrenal regulation of regional brain angiotensinogen content. Endocrinology. 106:337-342.

43. Gregory, T. J., C. J. Wallis, and M. P. Printz. 1982. Regional changes in rat brain angiotensinogen following bilateral nephrectomy. Hypertension. 4:827-838.

44. Ganten, D., K. Fuxe, M. I. Phillips, J. F. E. Mann, and U. Ganten. 1978. The brain isorenin-angiotensin system: biochemistry, localization, and possible role in drinking and blood pressure regulation. In Frontiers in Neuroendocrinology. W. F. Ganong and L. Martini, editors. Raven Press, New York. 5:61-99.

45. Lind, R. W., L. W. Swanson, and D. Ganten. 1985. Organization of angiotensin II immunoreactive cells and fibres in the rat central nervous system. Neuroendocrinology. 40:2-24.

46. Desjardins-Giasson, S., J. Gutkowska, R. Garcia, and J. Genest. 1981. Renin substrate in rat mesenteric artery. Can. J. Physiol. Pharmacol. 59:528-532.

47. Swales, J. D. 1979. Arterial wall or plasma renin in hypertension. Clin. Sci. 56:293-298.

48. Re, R., J. T. Fallon, V. Dzau, S. C. Ouay, and E. Haber. 1982. Renin synthesis by canine aortic smooth muscle cells in culture. Life Sci. 30:99-106.

49. Lilly, L. S., R. E. Pratt, R. W. Alexander, D. M. Larson, K. E. Ellison, M. A. Gimbrone, and V. J. Dzau. 1985. Renin expression by vascular endothelial cells in culture. Circ. Res. 57:312-318.

50. Fordis, C. M., J. S. Megorden, T. G. Ropchak, and H. R. Keiser. 1983. Absence of renin-like activity in rat aorta and microvessels. $\mathrm{Hy}$ pertension. 5:635-641.

51. Loudon, M., R. F. Bing, H. Thurston, and J. D. Swales. 1983. Arterial wall uptake of renal renin and blood pressure control. Hypertension. 5:629-634.

52. Celio, M. R., and T. Inagami. 1981. Angiotensin II immunoreactivity coexist with renin in the juxtaglomerular granular cells of the kidney. Proc. Natl. Acad. Sci. USA. 78:3897-3900.

53. Naruse, K., T. Inagami, M. R. Celio, R. J. Workman, and Y. Takii. 1982. Immunohistochemical evidence that angiotensins I and II are formed by intracellular mechanism in juxtaglomerular cells. Hypertension. 4(Suppl. 2):II-70-II-74.

54. Taugner, R., E. Hackenthal, U. Helmchen, D. Ganten, P. Kugler, M. Marin-Grez, R. Nobling, T. Unger, I. Lockwald, and R. Keilback. 1982. The intrarenal renin-angiotensin system. An immunocytochemical study on the localization of renin, angiotensinogen, converting enzyme and the angiotensins in the kidney of mouse and rat. Klin. Wochenschr. 60:1218-1222.

55. Morris, B. J., and C. I. Johnson. 1976. Renin substrate in granules from rat kidney cortex. Biochem. J. 154:625-637.

56. Misumi, J., J. Bouhnik, F. Alhenc-Gelas, P. Corvol, and J. Menard. 1983. Effects of circulating renin substrate on renal function in isolated perfused rat kidney. J. Hypertension. 1(Suppl. 2):40-42.

57. Richoux, J. P., J. L. Cordonnier, J. Bouhnik, E. Clauser, P. Corvol, J. Menard, and G. Grignon. 1983. Immunocytochemical localization of angiotensinogen in rat liver and kidney. Cell Tissue Res. 233:439-451.

58. Aguilera, G., A. Schirar, A. Baukal, and K. J. Catt. 1981. Circulating angiotensin II and adrenal receptors after nephrectomy. Nature (Lond.). 289:507-509.

59. Ganten, D., K. Hermann, T. Unger, and R. E. Lang. 1983. The tissue renin-angiotensin systems: focus on brain angiotensin, adrenal gland and arterial wall. Clin. Exp. Hypertens. [A]. 5:1099-1118.

60. Okamura, T., D. L. Clemens, and T. Inagami. 1984. Generation of angiotensins in cultured pheochromocytoma cells. Neuroscience Lett. 46:151-156.

61. Field, L. J., R. A. McGowan, D. P. Dickinson, and K. W. Gross. 1984. Tissue and gene specificity of mouse renin expression. Hypertension. 6:597-603.

62. Dzau, V. J., K. E. Ellison, and A. J. Ouelette. 1985. Expression and regulation of renin in the mouse heart. Clin. Res. 33:181A. (Abstr.)

63. Nieuwenhuis, J. J., and J. J. Theron. 1985. Cardiac substances that influence blood pressure. II. Potent pressor activity in rat and rabbit atrial muscle. Biochem. Biophys. Res. Commun. 129:472-478.

64. Swales, J. D., A. Abramovici, F. Beck, R. F. Bing, M. Loudon, and H. Thurston. 1983. Arterial wall renin. J. Hypertension. 1(Suppl. 1):17-22.

65. Reilly, C. F., D. A. Tewksbury, N. M. Schechter, and J. Travis. 1982. Rapid conversion of angiotensin I to angiotensin II by neutrophil and mast cell proteinases. J. Biol. Chem. 257:8619-8622.

66. Naruse, K., Y. Takii, and T. Inagami. 1981. Immunohistochemical localization of renin in luteinizing hormone producing cells of rat pituitary. Proc. Natl. Acad. Sci. USA. 78:7579-7583.

67. Steele, M. K., M. S. Brownfield, and W. F. Ganong. 1982. Immunocytochemical localization of angiotensin immunoreactivity in gonadotrops and lactotrops of the rat anterior pituitary gland. Neuroendocrinology. 35:155-158.

68. Pandey, K. N., K. S. Misono, and T. Inagami. 1984. Evidence for intracellular formation of angiotensins: coexistence of renin and angiotensin-converting enzyme in Leydig cells of rat testis. Biochem. Biophys. Res. Commun. 122:1337-1343.

69. Pandey, K. N., M. Maki, and T. Inagami. 1984. Detection of renin mRNA in mouse testis by hybridization with renin cDNA probe. Biochem. Biophys. Res. Commun. 125:662-667. 